\title{
Sensory, Microbial, Texture and Nutritional Evaluation of Okara Supplemented Probiotic Dhokla
}

\author{
Suman* and Neelam Khetarpaul \\ Department of Foods and Nutrition, CCS Haryana Agricultural University, Hisar, India \\ *Corresponding author
}

\begin{tabular}{|l|}
\hline Ke y w o r d s \\
$\begin{array}{l}\text { Soy, Okara, Dhokla, } \\
\text { Sensory, }\end{array}$ \\
$\begin{array}{l}\text { Fermentation, } \\
\text { Probiotic, Microbial, } \\
\text { Texture, Nutritional }\end{array}$ \\
\hline Article Info \\
\hline $\begin{array}{l}\text { Accepted: } \\
10 \text { March } 2018 \\
\text { Available Online: } \\
10 \text { April } 2018\end{array}$ \\
\hline
\end{tabular}

\section{Key words}

Sensory,

Fermentation,

Probiotic, Microbial,

Article Info

Accepted:

Available Online:

\section{A B S T R A C T}

In the present study dhokla was prepared by natural and probiotic ( $L$. acidophilus) fermentation with the supplementation of 10, 20 and 30 per cent okara powder. Results of organoleptic evaluation indicated that both naturally and probiotic fermented dhokla supplemented with 10 per cent okara powder were found most acceptable and 'liked moderately' by the judges. Mean scores of all the sensory attributes deceased significantly $(\mathrm{P}<0.05)$ as the level of okara powder supplementation increased from 10 to 30 per cent in both naturally and probiotic fermented dhokla. Hardness of both naturally and probiotic fermented dhokla increased significantly $(\mathrm{P}<0.05)$ as the level of okara powder supplementation increased from 10 to 30 per cent. The $\mathrm{pH}$ of naturally fermented batters of dhokla were significantly $(\mathrm{P}<0.05)$ lower as compared to their respective probiotic fermented counterparts. In both natural and probiotic fermentation, significant $(\mathrm{P}<0.05)$ difference was observed in between the titratable acidity of without okara and with okara powder supplemented batters dhokla. The counts of lactobacilli i.e. $7.2 \times 10^{10} \mathrm{cfu} / \mathrm{ml}$ in control and $6.8 \times 10^{10} \mathrm{cfu} / \mathrm{ml}$ in 10 per cent okara powder supplemented dhokla batters were maximum after $8 \mathrm{~h}$ of natural fermentation, followed by yeast cells i.e. $3.3 \times 10^{5}$ and $3.8 \times 10^{5} \mathrm{cfu} / \mathrm{ml}$ in control and 10 per cent okara powder supplemented dhokla batters, respectively. Whereas, the number of lactobacilli cells increased to $6.1 \times 10^{10}$ in control and $6.3 \times 10^{10}$ in okara powder (10\%) supplemented and probiotic fermented dhokla batters after $8 \mathrm{~h}$. A significant $(\mathrm{P}<0.05)$ decrease was brought about in crude protein, fat and crude fibre contents of naturally and probiotic fermented without okara dhokla over unfermented control. Supplementation of 10 per cent okara powder in dhokla whether fermented naturally or with probiotic microorganism significantly $(\mathrm{P}<0.05)$ increased the protein, fat, ash and crude fibre content.

\section{Introduction}

Currently an increase in knowledge of functional foods has led to develop foods with health benefits besides the basic role of nutrition. The traditional fermented foods contain high nutritive value and developed a diversity of flavours, aromas, and textures in food substrates. Now a day, food industries are focusing on different applications of probiotics in food products and creating a new generation of 'probiotic health' foods. Traditionally, probiotic products are usually marketed in the form of fermented milks and yogurts; however, with an increase in vegetarianism amongst consumers throughout 
developed countries, there is also a demand for vegetarian probiotic products (Ranadheera et al., 2010). The development of non-dairy Probiotic products is a challenge to the food industry in its effort to utilize the abundant natural resources by producing high quality functional products.

Several studies have shown that soy products may be good vehicles for probiotic microorganisms (Bedani et al., 2013; Champagne et al., 2009). The presence of probiotics in commercial food products has been claimed for certain health benefits.

Okara is a by-product with low commercial value generated during the manufacture of soymilk and is potentially a nutritious product high in fiber, protein, carbohydrates, vitamins, minerals and fat and has excellent functional properties (Li et al., 2012).

Since okara is a cheap and rich source of good quality protein and dietary fiber, many Asian countries have found a variety of ways to make use of okara in many food items such as soups, salads, baked goods and fermented food products such as tempeh (O'Toole, 1999).

Dhokla, a lactic acid fermented product, is originated in Gujarat, India which is mainly consumed as breakfast or snack food having tangy and slightly sweet in taste (Joshi et al., 1989; Roy et al., 2009). However, as it is prepared by using only either rice or semolina and chickpea it is essential to convert the traditional dhokla into nutritious dhokla with enhanced content of nutrients by value addition, so that, it can be used as functional food in addition to the daily diet.

Therefore, the present study was undertaken to develop probiotic dhokla incorporating okara and to study their sensory, microbial, textural and nutritional properties.

\section{Materials and Methods}

\section{Procurement of material}

The grains of soybean (cv. PS 1347) were procured in a single lot from the Department of Genetics and Plant Breeding, College of Agriculture, CCSHAU, Hisar. The seeds were cleaned and made free of dust, dirt and foreign materials and packed in air tight containers for further use. All the ingredients used for dhokla preparation were procured from local market. The culture of probiotic microorganism Lactobacillus acidophilus was purchased from the Microbial Culture Collection Centre, NDRI, Karnal.

\section{Extraction of okara}

Okara was extracted as per Chinese method. Soybean seeds were soaked overnight, rinsed and ground in a blender by adding water in 1:8 w/v to obtain the soy slurry; the resultant soy slurry was filtered through double layered cheese cloth. When filteration slowed, the remaining liquid was squeezed out by pressing with the hand for 1-2 min and the residue obtained (called okara) was freeze dried, ground to fine powder and stored in air tight polythene sheets for further use.

\section{Development of dhokla}

Okara based dhokla were prepared by supplementing okara powder at 10,20 and 30 per cent levels in bengal gram flour. Dholka prepared by bengal gram flour (100\%) served as control. For natural fermentation, all the batters of dhokla were kept in BOD incubator at $37^{\circ} \mathrm{C}$ temperature for 8 hours to carry out the fermentation, whereas, for probiotic fermentation, all the batters of dhokla were autoclaved at 15 psi for 15 minutes, cooled and then inoculated with probiotic curd containing $10^{8}$ cells $/ \mathrm{ml}$ and kept in BOD incubator at $37^{\circ} \mathrm{C}$ temperature for 8 hours. All 
the dhokla batters were steam cooked for 30 minutes in the dhokla cooker.

\section{Sensory evaluation of dhokla}

The developed dhoklas were subjected to sensory evaluation with respect to color, appearance, aroma, texture, taste and overall acceptability by a panel of 10 judges using the Nine-point Hedonic Rating Scale.

\section{Texture analysis of dhokla}

The texture analysis of dhoklas was analyzed using texture analyzer TA-HDI (Stable Micro Systems, Surrey, UK). The compression test was used for determination of firmness. The firmness was expressed as peak force $(\mathrm{Kg})$ of the first compression by a pre-set distance (i.e. force taken at $25 \%$ compression of $25 \mathrm{~mm}$ ) and expressed as force in Kilograms. The $5 \mathrm{~kg}$ compression load cell with $5 \mathrm{~mm}$ diameter (P/36R) cylindrical probe was used to compress the products. The pre-speed as well as post-speed of the probe was fixed at $1.0 \mathrm{~mm} / \mathrm{s}$ and $10 \mathrm{~mm} / \mathrm{s}$ and the test speed was $1.7 \mathrm{~mm} / \mathrm{s}$ during the compression test.

\section{Determination of titratable acidity and $\mathbf{p H}$ of dhokla batters}

Titratable acidity of fresh batters of the most acceptable dhokla before and after fermentation was determined as lactic acid per $100 \mathrm{ml}$ by the method of (AOAC, 2012). The $\mathrm{pH}$ of fresh batters of the most acceptable dhokla before and after fermentation was measured by a digital $\mathrm{pH}$ meter.

\section{Microbial analysis of dhokla batters}

The fresh batters of the most acceptable dhokla before and after fermentation were analyzed for lactobacillus, yeast, fungus and coliform. The batters were serially diluted with normal saline solution individually and appropriate dilutions were pour plated individually using MRS agar (for lactics), YEPDA (for yeasts), PDA (for fungus) and MacConkey's medium (for coliform) plates, incubated at $37^{\circ} \mathrm{C}$ for $24 \mathrm{~h}$ (Lactobacillus acidophilus), at $25^{\circ} \mathrm{C}$ for $72 \mathrm{~h}$ (yeast and fungus) and at $30^{\circ} \mathrm{C}$ for $48 \mathrm{~h}$ (coliform). The colonies were counted by pour plating method using a colony counter and results were expressed in terms of $\mathrm{cfu} / \mathrm{ml}$ of the sample.

\section{Nutritional composition of dhokla}

The organoleptically most acceptable dhokla and their respective unfermented control were oven dried at $55-60^{\circ} \mathrm{C}$ to a constant weight, ground in an electric grinder (cyclotec, M/S Tecator, Hoganas, Sweden using $0.5 \mathrm{~mm}$ sieve size) to a fine powder, stored in air tight polythene sheets and were analyzed for nutritional composition. The moisture, crude protein, crude fat, ash and crude fibre in the samples were estimated by using standard (AOAC, 2012) method. Crude protein was estimated using micro-Kjeldhal method using KEL PLUS Automatic Nitrogen Estimation System and a conversion factor of 6.25 was used to convert nitrogen into protein. Crude fat was determined by the soxhlet extraction method using Automatic SOCS plus Solvent Extraction System.

Crude fibre was estimated by acid and alkaline digestion method using Automatic Fibra plus system. The carbohydrate content was calculated by difference method by subtracting from 100 the sum of the percentage moisture, ash, protein, fat and fibre.

\section{Statistical analysis}

The data were statistically analyzed in a completely randomized design using analysis of variance to test the significant differences among treatments (Sheoran and Pannu, 1999). 


\section{Results and Discussion}

\section{Organoleptic characteristics of dhokla}

Mean scores of colour, appearance, aroma, texture, taste and overall acceptability of okara supplemented dhokla are presented in Table 1. The natural and probiotic fermented control dhokla containing 100 per cent bengal gram flour had maximum mean scores for colour (8.3 and 8.2), appearance (8.2 and 8.0), aroma (8.1 and 8.0), texture (8.2 and 8.0), taste $(8.1$ and 8.1$)$ and overall acceptability (8.18 and 8.06) which fell in the category of 'liked very much'. A significant $(\mathrm{P}<0.05)$ difference was observed for colour between control and 10 per cent okara powder supplemented dhokla fermented naturally and with probiotic organism, whereas, appearance, aroma, texture, taste and overall acceptability of naturally and probiotic fermented control and that containing 10 per cent okara powder dhokla did not differ significantly. Mean scores of all the sensory characteristics i.e. colour (7.8), aroma (7.8 and 7.7), texture (7.7), taste (7.6 and 7.8) and overall acceptability (7.78 and 7.78) of 10 per cent okara powder supplemented dhokla fermented naturally and with probiotic organism were significantly $(\mathrm{P}<0.05)$ higher than supplemented dhokla containing 20 and 30 per cent okara powder and fell in the category of 'liked moderately'. The appearance of naturally (8.0) and probiotic (7.9) fermented 10 per cent okara powder supplemented dhokla fell in the category of 'liked very much' and 'liked moderately', respectively. Mean scores of all the sensory attributes deceased significantly $(\mathrm{P}<0.05)$ as the level of okara powder supplementation in dhokla increased from 10 to 30 per cent in both natural and probiotic fermentation. Mean scores of various sensory characteristics of dhokla made by supplementation of 20 per cent okara powder were 'liked slightly' except taste (5.9) of naturally fermented 20 per cent okara powder supplemented dhokla which was 'neither liked nor disliked' by the judges. On the other hand, in both natural and probiotic fermentation, the lowest mean scores were observed for 30 per cent okara powder supplemented dhokla for appearance (6.0 and 6.25) and aroma (6.1 and 6.3) which fell in the category of 'liked slightly', whereas, 'neither liked nor disliked' for texture (5.4 and 5.65), taste (5.0 and 5.4) and overall acceptability (5.68 and 5.96). The colour of naturally (5.9) and probiotic (6.2) fermented 30 per cent okara powder supplemented dhokla fell in the category of 'neither liked nor disliked' and 'liked slightly', respectively.

For all the sensory characteristics, no significant $(\mathrm{P}<0.05)$ differences were observed between the naturally and probiotic fermented dhokla supplemented with okara. It may be concluded that dhokla whether fermented naturally or with probiotic organism and containing 10 per cent level of okara powder were found acceptable in terms of their overall acceptability. Gadhe et al., (2010) reported that replacement of bengal gram by soybean in dhokla was found acceptable in respect to their sensory characteristics.

\section{Texture analysis of dhokla}

The data for texture analysis of dhokla has been presented in Table 2. Hardness of naturally and probiotic fermented control dhokla were 11.25 and 12.62 Newtons, respectively. Naturally (12.78 Newton) and probiotic (14.25 Newton) fermented dhokla containing 10 per cent okara powder had significantly $(\mathrm{P}<0.05)$ more hardness as compared to control dhokla. Hardness of both naturally and probiotic fermented dhokla increased as the level of okara powder supplementation increased from 10 to 30 per cent. Naturally and probiotic fermented dhokla containing 30 per cent okara powder had significantly $(\mathrm{P}<0.05)$ the highest hardness 
and it was 23.02 and 25.76 Newtons, significantly $(\mathrm{P}<0.05)$ more hardness than respectively. Probiotic fermented control and those of their respective naturally fermented okara powder supplemented dhokla had counterparts.

Table.1 Mean scores of sensory characteristics of okara supplemented dhokla

\begin{tabular}{|c|c|c|c|c|c|c|}
\hline \multirow[t]{2}{*}{ Types of dhokla } & \multicolumn{2}{|c|}{ Types of fermentation } & \multirow[t]{2}{*}{ Mean } & \multicolumn{2}{|c|}{ Types of fermentation } & \multirow[t]{2}{*}{ Mean } \\
\hline & Natural & Probiotic & & Natural & Probiotic & \\
\hline & \multicolumn{3}{|c|}{ Colour } & \multicolumn{3}{|c|}{ Appearance } \\
\hline $\begin{array}{l}\text { Control } \\
\text { Bengal gram flour }(\mathbf{1 0 0 \%})\end{array}$ & $8.3 \pm 0.15$ & $8.2 \pm 0.20$ & 8.25 & $8.2 \pm 0.13$ & $8.0 \pm 0.21$ & 8.10 \\
\hline $\begin{array}{l}\text { Type-I } \\
\text { Bengal gram flour:Okara powder }(90: 10)\end{array}$ & $7.8 \pm 0.13$ & $7.8 \pm 0.20$ & 7.80 & $8.0 \pm 0.21$ & $7.9 \pm 0.23$ & 7.95 \\
\hline $\begin{array}{l}\text { Type-II } \\
\text { Bengal gram flour:Okara powder }(80: 20)\end{array}$ & $6.9 \pm 0.10$ & $6.7 \pm 0.15$ & 6.80 & $6.7 \pm 0.34$ & $6.85 \pm 0.21$ & 6.78 \\
\hline $\begin{array}{l}\text { Type-II } \\
\text { Bengal gram flour:Okara powder (70:30) }\end{array}$ & $5.9 \pm 0.31$ & $6.2 \pm 0.25$ & 6.05 & $6.0 \pm 0.33$ & $6.25 \pm 0.34$ & 6.13 \\
\hline Mean & 7.23 & 7.23 & & 7.23 & 7.25 & \\
\hline \multirow[t]{2}{*}{$\mathrm{CD}(\mathrm{P} \leq 0.05)$} & \multicolumn{3}{|c|}{$\begin{array}{l}\text { Type } 0.40 \text { Treatment NS } \\
\text { Interaction NS }\end{array}$} & \multicolumn{3}{|c|}{$\begin{array}{l}\text { Type } 0.52 \text { Treatment NS } \\
\text { Interaction NS }\end{array}$} \\
\hline & \multicolumn{3}{|c|}{ Aroma } & \multicolumn{3}{|c|}{ Texture } \\
\hline $\begin{array}{l}\text { Control } \\
\text { Bengal gram flour }(\mathbf{1 0 0 \%})\end{array}$ & $8.1 \pm 0.10$ & $8.0 \pm 0.16$ & 8.05 & $8.2 \pm 0.13$ & $8.0 \pm 0.15$ & 8.10 \\
\hline $\begin{array}{l}\text { Type-I } \\
\text { Bengal gram flour:Okara powder }(90: 10)\end{array}$ & $7.8 \pm 0.13$ & $7.7 \pm 0.17$ & 7.75 & $7.7 \pm 0.21$ & $7.7 \pm 0.21$ & 7.70 \\
\hline $\begin{array}{l}\text { Type-II } \\
\text { Bengal gram flour:Okara powder }(\mathbf{8 0 : 2 0 )}\end{array}$ & $6.5 \pm 0.37$ & $6.7 \pm 0.21$ & 6.60 & $6.2 \pm 0.29$ & $6.4 \pm 0.22$ & 6.30 \\
\hline $\begin{array}{l}\text { Type-III } \\
\text { Bengal gram flour:Okara powder (70:30) }\end{array}$ & $6.1 \pm 0.43$ & $6.3 \pm 0.21$ & 6.20 & $5.4 \pm 0.52$ & $5.65 \pm 0.32$ & 5.53 \\
\hline Mean & 7.13 & 7.18 & & 6.88 & 6.94 & \\
\hline \multirow[t]{2}{*}{$\mathrm{CD}(\mathrm{P} \leq 0.05)$} & \multicolumn{3}{|c|}{$\begin{array}{l}\text { Type } 0.55 \text { Treatment NS } \\
\text { Interaction NS }\end{array}$} & \multicolumn{3}{|c|}{$\begin{array}{l}\text { Type } 0.56 \text { Treatment NS } \\
\text { Interaction NS }\end{array}$} \\
\hline & \multicolumn{3}{|c|}{ Taste } & \multicolumn{3}{|c|}{ Overall acceptability } \\
\hline $\begin{array}{l}\text { Control } \\
\text { Bengal gram flour }(\mathbf{1 0 0 \%})\end{array}$ & $8.1 \pm 0.10$ & $8.1 \pm 0.23$ & 8.10 & $8.18 \pm 0.08$ & $8.06 \pm 0.17$ & 8.12 \\
\hline $\begin{array}{l}\text { Type-I } \\
\text { Bengal gram flour:Okara powder }(90: 10)\end{array}$ & $7.6 \pm 0.22$ & $7.8 \pm 0.33$ & 7.70 & $7.78 \pm 0.14$ & $7.78 \pm 0.20$ & 7.78 \\
\hline $\begin{array}{l}\text { Type-II } \\
\text { Bengal gram flour:Okara powder }(\mathbf{8 0 : 2 0 )}\end{array}$ & $5.9 \pm 0.38$ & $6.2 \pm 0.20$ & 6.08 & $6.45 \pm 0.27$ & $6.57 \pm 0.14$ & 6.51 \\
\hline $\begin{array}{l}\text { Type-III } \\
\text { Bengal gram flour:Okara powder (70:30) }\end{array}$ & $5.0 \pm 0.52$ & $5.4 \pm 0.31$ & 5.20 & $5.68 \pm 0.39$ & $5.96 \pm 0.29$ & 5.82 \\
\hline Mean & 6.66 & 6.88 & & 7.02 & 7.09 & \\
\hline $\mathrm{CD}(\mathrm{P} \leq 0.05)$ & \multicolumn{3}{|c|}{$\begin{array}{c}\text { Type } 0.62 \text { Treatment NS } \\
\text { Interaction NS }\end{array}$} & \multicolumn{3}{|c|}{$\begin{array}{c}\text { Type } 0.48 \text { Treatment NS } \\
\text { Interaction NS }\end{array}$} \\
\hline
\end{tabular}

Values are mean $\pm \mathrm{SE}$ of ten independent determinations 
Table.2 Texture analysis (Newtons) of dhokla

\begin{tabular}{|c|c|c|c|}
\hline \multirow[t]{2}{*}{ Types of dhokla } & \multicolumn{2}{|c|}{ Types of fermentation } & \multirow[t]{2}{*}{ Mean } \\
\hline & Natural fermentation & Probiotic fermentation & \\
\hline $\begin{array}{l}\text { Control } \\
\text { Bengal gram flour (100\%) }\end{array}$ & $11.25 \pm 0.18$ & $12.62 \pm 0.60$ & 11.93 \\
\hline $\begin{array}{l}\text { Type-I } \\
\text { Bengal gram flour:Okara } \\
\text { powder }(90: 10)\end{array}$ & $12.78 \pm 0.61$ & $14.25 \pm 0.42$ & 13.52 \\
\hline $\begin{array}{l}\text { Type-II } \\
\text { Bengal gram flour:Okara } \\
\text { powder }(80: 20)\end{array}$ & $17.65 \pm 1.28$ & $20.06 \pm 0.64$ & 18.86 \\
\hline $\begin{array}{l}\text { Type-III } \\
\text { Bengal gram flour:Okara } \\
\text { powder }(70: 30)\end{array}$ & $23.02 \pm 0.46$ & $25.76 \pm 0.55$ & 24.39 \\
\hline Mean & 16.18 & 18.17 & \\
\hline $\mathrm{CD}(\mathrm{P} \leq 0.05)$ & Type 1.4 & nt 0.99 Interaction NS & \\
\hline
\end{tabular}

Values are mean $\pm \mathrm{SE}$ of three independent determinations

Table.3 Effect of fermentation on $\mathrm{pH}$ and titratable acidity (\% lactic acid) of dhokla batters

\begin{tabular}{|c|c|c|}
\hline Types of dhokla batters & pH & Titratable acidity \\
\hline $\begin{array}{l}\text { Bengal gram flour }(\mathbf{1 0 0 \%}) \\
\text { Unfermented Control }\end{array}$ & $5.28 \pm 0.02$ & $0.28 \pm 0.04$ \\
\hline \multicolumn{3}{|l|}{ Natural fermentation } \\
\hline Bengal gram flour:Okara powder (100:0) & $4.70 \pm 0.02$ & $0.85 \pm 0.02$ \\
\hline Bengal gram flour:Okara powder $(90: 10)$ & $4.66 \pm 0.02$ & $0.94 \pm 0.01$ \\
\hline \multicolumn{3}{|l|}{ Probiotic fermentation } \\
\hline Bengal gram flour:Okara powder (100:0) & $4.84 \pm 0.01$ & $0.62 \pm 0.02$ \\
\hline Bengal gram flour:Okara powder (90:10) & $4.72 \pm 0.01$ & $0.78 \pm 0.03$ \\
\hline $\mathrm{CD}(\mathrm{P} \leq 0.05)$ & 0.05 & 0.08 \\
\hline
\end{tabular}

Values are mean $\pm \mathrm{SE}$ of three independent determinations

Table.4 Effect of fermentation on microbial count of dhokla batters (cfu/ml)

\begin{tabular}{|c|c|c|c|c|c|}
\hline \multirow[t]{3}{*}{ Organism } & \multirow{3}{*}{$\begin{array}{l}\text { Period of } \\
\text { fermentatio } \\
\text { n (hour) }\end{array}$} & \multicolumn{4}{|c|}{ Types of fermentation } \\
\hline & & \multicolumn{2}{|c|}{ Natural fermentation } & \multicolumn{2}{|c|}{ Probiotic fermentation } \\
\hline & & $\begin{array}{c}\text { Control } \\
\text { Bengal gram } \\
\text { flour }(\mathbf{1 0 0 \%})\end{array}$ & $\begin{array}{c}\text { Bengal gram } \\
\text { flour: Okara } \\
\text { powder }(90: 10)\end{array}$ & $\begin{array}{c}\text { Control } \\
\text { Bengal gram } \\
\text { flour }(100 \%)\end{array}$ & $\begin{array}{c}\text { Bengal gram } \\
\text { flour: Okara } \\
\text { powder }(90: 10)\end{array}$ \\
\hline \multirow{2}{*}{$\begin{array}{l}\text { Lacto } \\
\text { bacillus }\end{array}$} & 0 & $4.8 \times 10^{6}$ & $3.6 \times 10^{6}$ & - & - \\
\hline & 8 & $7.2 \times 10^{10}$ & $6.8 \times 10^{10}$ & $6.1 \times 10^{10}$ & $6.3 \times 10^{10}$ \\
\hline \multirow[t]{2}{*}{$\begin{array}{l}\text { Yeast } \\
\end{array}$} & 0 & $3.1 \times 10^{4}$ & $3.3 \times 10^{4}$ & - & - \\
\hline & 8 & $3.3 \times 10^{5}$ & $3.8 \times 10^{5}$ & - & - \\
\hline \multirow[t]{2}{*}{ Coliform } & 0 & $2.0 \times 10^{2}$ & $1.7 \times 10^{2}$ & - & - \\
\hline & 8 & $2.5 \times 10^{3}$ & $2.1 \times 10^{3}$ & - & - \\
\hline \multirow[t]{2}{*}{ Fungus } & 0 & - & - & - & - \\
\hline & 8 & - & - & - & - \\
\hline
\end{tabular}

Values are mean of three independent determinations 
Table.5 Effect of fermentation on nutrient composition of dhokla (g/100 g, dry weight basis)

\begin{tabular}{|c|c|c|c|c|c|c|}
\hline $\begin{array}{c}\text { Types of } \\
\text { dhokla }\end{array}$ & Moisture & $\begin{array}{l}\text { Crude } \\
\text { protein }\end{array}$ & Fat & Ash & $\begin{array}{l}\text { Crude } \\
\text { fiber }\end{array}$ & Carbohydrate \\
\hline $\begin{array}{l}\text { Bengal gram } \\
\text { flour }(\mathbf{1 0 0 \%}) \\
\text { Unfermented } \\
\text { Control } \\
\end{array}$ & $3.80 \pm 0.09$ & $20.56 \pm 0.25$ & $5.32 \pm 0.07$ & $4.84 \pm 0.08$ & $3.35 \pm 0.04$ & $62.13 \pm 0.43$ \\
\hline \multicolumn{7}{|c|}{ Natural fermentation } \\
\hline $\begin{array}{l}\text { Bengal gram } \\
\text { flour:Okara } \\
\text { powder } \\
(\mathbf{1 0 0 : 0 )} \\
\end{array}$ & $3.93 \pm 0.04$ & $\begin{array}{c}16.33 \pm 0.38 \\
(-20.57)\end{array}$ & $\begin{array}{c}3.84 \pm 0.02 \\
(-27.82)\end{array}$ & $4.63 \pm 0.04$ & $\begin{array}{c}2.85 \pm 0.03 \\
(-14.93)\end{array}$ & $\begin{array}{c}68.42 \pm 0.35 \\
(+10.12)\end{array}$ \\
\hline $\begin{array}{l}\text { Bengal gram } \\
\text { flour:Okara } \\
\text { powder } \\
(90: 10) \\
\end{array}$ & $4.11 \pm 0.04$ & $\begin{array}{c}17.21 \pm 0.29 \\
(-16.29)\end{array}$ & $\begin{array}{c}4.42 \pm 0.06 \\
(-16.92)\end{array}$ & $4.52 \pm 0.13$ & $\begin{array}{c}4.54 \pm 0.07 \\
(+35.52)\end{array}$ & $\begin{array}{c}65.20 \pm 0.38 \\
\quad(+4.94)\end{array}$ \\
\hline \multicolumn{7}{|c|}{ Probiotic fermentation } \\
\hline $\begin{array}{l}\text { Bengal gram } \\
\text { flour:Okara } \\
\text { powder } \\
(\mathbf{1 0 0 : 0 )}\end{array}$ & $3.87 \pm 0.10$ & $\begin{array}{c}16.48 \pm 0.64 \\
(-19.84)\end{array}$ & $\begin{array}{c}3.90 \pm 0.04 \\
(-26.69)\end{array}$ & $4.75 \pm 0.06$ & $\begin{array}{c}2.78 \pm 0.09 \\
(-17.01)\end{array}$ & $\begin{array}{c}68.23 \pm 0.78 \\
\quad(+9.82)\end{array}$ \\
\hline $\begin{array}{l}\text { Bengal gram } \\
\text { flour:Okara } \\
\text { powder } \\
(90: 10) \\
\end{array}$ & $3.97 \pm 0.05$ & $\begin{array}{c}17.35 \pm 0.64 \\
(-15.61)\end{array}$ & $\begin{array}{c}4.50 \pm 0.05 \\
(-15.41)\end{array}$ & $4.62 \pm 0.06$ & $\begin{array}{c}4.50 \pm 0.06 \\
(+34.33)\end{array}$ & $\begin{array}{c}65.05 \pm 0.62 \\
\quad(+4.70)\end{array}$ \\
\hline $\mathrm{CD}(\mathrm{P} \leq 0.05)$ & NS & 1.06 & 0.17 & NS & 0.19 & 1.72 \\
\hline
\end{tabular}

Values are mean $\pm \mathrm{SE}$ of three independent determinations

Values in parentheses indicate per cent increase/decrease over unfermented without okara control

Effect of fermentation on $\mathrm{pH}$ and titratable acidity of dhokla batters

The data pertaining to the effect of fermentation on $\mathrm{pH}$ and titratable acidity of dhokla batters is presented in Table 3. The unfermented control dhokla containing 100 per cent bengal gram flour had $5.28 \mathrm{pH}$ and 0.28 per cent titratable acidity. The $\mathrm{pH}$ of naturally (4.70 and 4.66) and probiotic (4.84 and 4.72) fermented without okara and 10 per cent okara powder supplemented dhokla batters decreased significantly $(\mathrm{P}<0.05)$ over the unfermented control, respectively. The $\mathrm{pH}$ of naturally fermented without okara and 10 per cent okara powder supplemented dhokla batters were significantly $(\mathrm{P}<0.05)$ less as compared to their respective probiotic fermented counterparts. No significant difference was observed between without okara and 10 per cent okara powder supplemented dhokla batters when fermented naturally, whereas, it differed significantly $(\mathrm{P}<0.05)$ when fermented with probiotic organism. The titratable acidity of naturally $(0.85$ and $0.94 \%)$ and probiotic $(0.62$ and $0.78 \%$ ) fermented dhokla batters without okara and 10 per cent okara powder increased significantly $(\mathrm{P}<0.05)$ over the unfermented control. The titratable acidity of naturally fermented dhokla batters without okara and 10 per cent okara powder were significantly $(\mathrm{P}<0.05)$ higher than those of their respective probiotic fermented counterparts. A significant $(\mathrm{P}<0.05)$ difference was observed in the 
titratable acidity of dhokla batters without okara and containing 10 per cent okara powder when subjected to both natural and probiotic fermentation. Similar drop in $\mathrm{pH}$ and increase in titratable acidity was reported in dhokla by various workers (Roy et al., 2007; Gadhe et al., 2010; Patel et al., 2013; Lai, 2014).

\section{Effect of fermentation on microbial count of dhokla batters}

The data regarding the effect of fermentation on microbial count of dhokla batters is given in Table 4. The counts of lactobacillus $\left(4.8 \times 10^{6}\right.$ $\mathrm{cfu} / \mathrm{ml})$ and yeast $\left(3.1 \times 10^{4} \mathrm{cfu} / \mathrm{ml}\right)$ present naturally in control and 10 per cent okara powder supplemented $\left(3.6 \times 10^{6} \mathrm{cfu} / \mathrm{ml}\right.$ lactobacilli and $3.3 \times 10^{4} \mathrm{cfu} / \mathrm{ml}$ yeast) dhokla batters showed a progressive increase in their numbers after fermentation for $8 \mathrm{~h}$. After $8 \mathrm{~h}$ of natural fermentation, the maximum increase in cell number was observed for lactobacilli i.e. $7.2 \times 10^{10} \mathrm{cfu} / \mathrm{ml}$ in control and $6.8 \times 10^{10} \mathrm{cfu} / \mathrm{ml}$ in 10 per cent okara powder supplemented dhokla batters followed by yeast cells i. e. $3.3 \times 10^{5}$ and $3.8 \times 10^{5} \mathrm{cfu} / \mathrm{ml}$ in control and 10 per cent okara powder supplemented dhokla batters, respectively.

The number of coliforms increased from $2.0 \times 10^{2}$ to $2.5 \times 10^{3}$ and $1.7 \times 10^{2}$ to $2.1 \times 10^{3}$ in control and 10 per cent okara powder supplemented and naturally fermented dhokla batters. Fungus cells were not found in any of the dhokla batters. Upon $8 \mathrm{~h}$ probiotic fermentation, the number of lactobacillus cells increased to $6.1 \times 10^{10}$ in control and $6.3 \times 10^{10}$ in okara powder (10\%) supplemented and probiotic fermented dhokla batters. Increase in microbial count of dhokla was reported by Joshi et al., (1989) and Gadhe et al., (2010) too.

\section{Effect of fermentation on nutrient composition of dhokla}

The data regarding effect of fermentation on nutrient composition of dhokla has been presented in Table 5. The moisture contents of naturally (3.93 and $4.11 \mathrm{~g} / 100 \mathrm{~g}$ ) and probiotic (3.87 and $3.97 \mathrm{~g} / 100 \mathrm{~g})$ fermented without okara and 10 per cent okara powder supplemented dhokla were almost similar to that of unfermented without okara control (3.80 g/100 g) dhokla. Moisture contents of present study were in the range of those reported by Bhama et al., (2006). The crude protein content of unfermented without okara control dhokla was $20.56 \mathrm{~g} / 100 \mathrm{~g}$ which decreased significantly $(\mathrm{P}<0.05)$ after natural $(16.33 \mathrm{~g} / 100$ g) and probiotic $(16.48 \mathrm{~g} / 100 \mathrm{~g})$ fermentation i.e. 20.57 and 19.84 per cent, respectively over the unfermented control dhokla. Also, the protein contents of naturally $(17.21 \mathrm{~g} / 100 \mathrm{~g})$ and probiotic (17.35 g/100 g) fermented containing 10 per cent okara powder dhokla were significantly $(\mathrm{P}<0.05)$ reduced i.e. by 16.29 and 15.61 per cent over the unfermented without okara control dhokla. Similarly, significant decrease in protein content after fermentation was reported by Sindhu and Khetarpaul (2005) in single and sequential cuture culture fermentation of cereal and pulse food mixtures and Arora et al., (2010) for $L$. acidophilus fermentation of barley food mixture. In both naturally and probiotic fermented dhokla prepared by supplementation of 10 per cent okara powder in it had significantly $(\mathrm{P}<0.05)$ more protein content than that observed in without okara dhokla. Similar protein content was reported by Bhama et al., (2006) and Gadhe et al., (2010) for control dhokla. The fat content of naturally $(3.84 \mathrm{~g} / 100$ g) and probiotic $(3.90 \mathrm{~g} / 100 \mathrm{~g})$ fermented dhokla without okara decreased significantly $(\mathrm{P}<0.05)$ over the unfermented without okara control (5.32 g/100 g) dhokla. Similarly, a significant $(\mathrm{P}<0.05)$ decrease was observed in the fat content of 10 per cent okara powder supplemented dhokla fermented naturally (4.42 $\mathrm{g} / 100 \mathrm{~g})$ and with probiotic $(4.50 \mathrm{~g} / 100 \mathrm{~g})$ organism over the unfermented control dhokla. A significant $(\mathrm{P}<0.05)$ decrease was observed in both natural and probiotic fermented without okara (27.82 and 26.69\%) as well as 10 per cent okara powder supplemented (16.92 and $15.41 \%$ ) dhokla. The fat contents of both naturally and probiotic fermented dhokla having 
10 per cent okara powder were significantly $(\mathrm{P}<0.05)$ more than that of naturally and probiotic fermented dhoklas without okara. Decrease in fat content may be attributed to the breakdown of fatty acid and glycerol by lipolytic organism present in the sample during fermentation. The decrease in fat content was also reported earlier by Ojokoh and Bello (2014) in soybean and Marko et al., (2014) in cereals. Bhama et al., (2006) reported higher values for fat content of control dhokla than that found in present study. The ash contents of naturally (4.63 and $4.52 \mathrm{~g} / 100 \mathrm{~g}$ ) and probiotic (4.75 and $4.62 \mathrm{~g} / 100 \mathrm{~g})$ fermented dhokla without okara and 10 per cent okara powder supplementation were statistically almost similar to that of unfermented without okara control (4.84 g/100 g) dhokla. The results found in present study for control dhokla are on the similar lines as those reported previously by Bhama et al., (2006), whereas, Kalaiyarasi and Kaimathi (2014) reported lower values for ash content of dhokla. The crude fibre content of naturally $(2.85 \mathrm{~g} / 100 \mathrm{~g})$ and probiotic (2.78 $\mathrm{g} / 100 \mathrm{~g})$ fermented dhokla without okara decreased significantly $(\mathrm{P}<0.05)$ i.e. 14.93 and 17.01 per cent over the unfermented without okara control (3.35 g/100 g) dhokla. The crude fibre content was $4.54 \mathrm{~g} / 100 \mathrm{~g}$ in naturally and $4.50 \mathrm{~g} / 100 \mathrm{~g}$ in probiotic fermented and 10 per cent okara powder supplemented dhokla. Supplementation of 10 per cent okara powder in dhokla significantly $(\mathrm{P}<0.05)$ increased the crude fibre content of naturally $(35.52 \%)$ as well as probiotic $(34.33 \%)$ fermented dhokla over the unfermented without okara control dhokla. Bhama et al., (2006) reported lower values for crude fibre content in dhokla. The carbohydrates content of unfermented without okara control dhokla was $62.13 \mathrm{~g} / 100 \mathrm{~g}$ and it increased significantly $(\mathrm{P}<0.05)$ in naturally $(68.42 \mathrm{~g} / 100 \mathrm{~g})$ and probiotic $(68.23 \mathrm{~g} / 100 \mathrm{~g})$ fermented without okara dhokla i.e. 10.12 and 9.82 per cent, respectively over the unfermented without okara control dhokla. The carbohydrate content in naturally and probiotic fermented dhoklas which contained 10 per cent okara powder were 65.20 and $65.05 \mathrm{~g} / 100 \mathrm{~g}$, respectively, and were significantly $(\mathrm{P}<0.05)$ increased to 4.94 and 4.70 per cent, respectively over the unfermented without okara control dhokla. Similar range for carbohydrate contents in control dhokla were reported by Bhama et al., (2006) and Gadhe et al., (2010).

It may be concluded from the present study that development of value added probiotic dhokla by incorporating okara is not only organoleptically acceptable but also nutritionally rich and explores the possibility of utilizing this valuable byproduct which is rich in protein, fibre, minerals and antioxidants and consumption of such products can serve as functional foods with health potential.

\section{References}

AOAC. 2012. Official Methods of Analysis, $19^{\text {th }}$ edition. Association of the Official Analytical Chemists, Washington D.C, USA.

Arora, S., Jood, S. and Khetarpaul, N. 2010. Effect of germination and probiotic fermentation on nutrient composition of barley based food mixtures. Food Chemistry. 119: 779-784.

Bedani, R., Rossi, E.A., and Saad, S.M.I. 2013. Impact of inulin and okara on Lactobacillus acidophilus La-5 and Bifidobacterium animalis $\mathrm{Bb}-12$ viability in a fermented soy product and probiotic survival under in vitro simulated gastrointestinal conditions. Food Microbiology. 34: 382-389.

Bhama, S., Sadana, B.K. and Malhotra, S.R. 2006. Mineral availability of chickpea (Cicer arietinum) processed products. Beverage and Food World. 4: 60-62.

Champagne, C.P., Green-Johnson, J.M., Raymond, Y., Barrette, J. and Buckley, N.D. 2009. Selection of probiotic bacteria for the fermentation of a soy beverage in combination with Streptococcus thermophilus. Food Research International. 42(5-6): 612-621.

Gadhe, K.S., Jadhav, B.A. and Kshirsagar, R.B. 2010. Utilization of soyabean in dhokla preparation. Bioinfolet. 7(4): 309-312. 
Joshi, N., Godbole, S.H. and Kanekar, P. 1989. Microbiological and biochemical changes during dhokla fermentation with special reference to flavor compounds. Journal of Food Science and Technology. 26: 113115.

Kalaiyarasi, C. and Kalaimathi, J. 2014. Preparation of fermented foods-tofu and dhokla and bio evaluating its nutritional and sensory properties. International Journal of Innovation in Pharma Biosciences and Research Technology. 1(1): 1-8.

Lai, Wing-Fu. 2014. Progress in biotechnology for food applications Chapter: Fermentation technologies in food production Edited by: Wing-Fu Lai, Published by OMICS Group eBooks 731 Gull Ave, Foster City. CA 94404, USA.

Li, B., Qiao, M. and Lu, F. 2012. Composition, nutrition and utilization of okara (soybean residue). Food Reviews International. 28(3): 231-252.

Marko, A., Rakická, M., Mikušová, L., Valík, L. and Šturdík, E. 2014. Lactic acid fermentation of cereal substrates in nutritional perspective. International Journal of Research in Chemistry and Environment. 4(4): 80-92.

Ojokoh, A. and Bello, B. 2014. Effect of fermentation on nutrient and anti-nutrient composition of millet (Pennisetum glaucum) and soyabean (Glycine max) blend flours. Journal of Life Sciences. 8(8): 668-675.
O'Toole, D.K. 1999. Characteristics and use of okara, the soybean residue from soy milk production A Review. Journal of Agricultural and Food Chemistry. 47: 363-371.

Patel, D.N., Sutar, P.P. and Sutar, N. 2013. Development of instant fermented cereallegume mix using pulsed microwave vacuum drying. Drying technology: An International Journal. 31(3): 314-328.

Ranadheera, R. Baines, SK and Adams, M.C. 2010. Importance of food in probiotic efficacy. Food Research International. 43(1):1 -7.

Roy, A., Bijoy, M. and Prabir, S.K. 2009. Survival and growth of foodborne bacterial pathogens in fermenting batters of dhokla. Journal of Food Science and Technology. 46:132-135.

Roy, A., Moktan, B. and Sarkar, P.K. 2007. Microbiological quality of legume-based traditional fermented foods marketed in West Bengal, India. Food Control. 18: 1405-1411.

Sheoran, O.P., Pannu, R.S. 1999. Statistical software package for agricultural research workers in recent advances in information theory, Statistics and Computer application. (Eds. Hooda, D.S. and Hasija, R.C. 139-143.

Sindhu, S.C. and Khetarpaul, N. 2005. Development, acceptability and nutritional evaluation of an indigenous food blend fermented with probiotic organisms. Nutrition and Food Science. 35: 20-27.

\section{How to cite this article:}

Suman and Neelam Khetarpaul. 2018. Sensory, Microbial, Texture and Nutritional Evaluation of Okara Supplemented Probiotic Dhokla. Int.J.Curr.Microbiol.App.Sci. 7(04): 1274-1283. doi: https://doi.org/10.20546/ijcmas.2018.704.142 